\title{
Composition and structure of a stretch of tropical forest in the Eastern Amazon
}

\author{
Robson Carmo Lima ${ }^{1 *}$ Maurício Alves Sardinha ${ }^{1}$ Jefferson dos Santos Souza ${ }^{2}$ Renan Sousa ${ }^{2}$ \\ Valdenira Ferreira dos Santos $^{3}$ Perseu da Silva Aparício ${ }^{4}$ Pierre Couteron ${ }^{5}$ \\ Eleneide Doff Sotta ${ }^{6}$ Breno Marques da Silva e Silva ${ }^{4}$
}

\author{
${ }_{1}^{1}$ Universidade Federal do Amapá (Unifap), 68926-096, Santana, AP, Brasil. E-mail: robsonc191@hotmail.com. "Corresponding author. \\ ${ }^{2}$ Instituto Macapaense do Melhor Ensino Superior (IMMES), Macapá, AP, Brasil. \\ ${ }^{3}$ Instituto de Pesquisas Científicas e Tecnológicas do Estado do Amapá (IEPA), Macapá, AP, Brasil. \\ ${ }^{4}$ Universidade do Estado do Amapá (UEAP), Macapá, AP, Brasil. \\ ${ }^{5}$ Institut de Recherche pour le Développement (IRD), Montpelier, França. \\ ${ }^{6}$ Empresa Brasileira de Pesquisa Agropecuária, Embrapa Amazônia Oriental, Macapá, AP, Brasil.
}

\begin{abstract}
The aim of this study was to determine the diversity. composition. forest structure of a stretch of dense ombrophilous forest in the state of Amapá. The area is located in the east of the state of Amapá. in the Eastern Amazon. at the following coordinates: $2^{\circ} 0$ '0.00 " $N$. $14^{\circ} 0^{\prime} 0.00^{\prime \prime} O$. The sampling process used was systematic. where nine plots of 1 ha $(100 \mathrm{~m} \times 100 \mathrm{~m})$ were allocated. $0.5 \mathrm{~km}$ apart. within a 13 $\mathrm{km}$ long and $0.03 \mathrm{~km}$ wide transect. The horizontal structure of the forest was evaluated using phytosociological parameters. One thousand seven hundred and ninety trees were sampled in this study. they were distributed in 131 species. 69 genera and 48 families. The species that presented more individuals were Pouteria guianensis Aubl. (136). Eschweilera coriacea (DC.) S.A.Mori (78). Inga paraensis Ducke (45). Licania paraensis Prance (38). The area is highly diverse and dissimilar with great variability and complexity in vegetable formation. Key words: Diversity, Diametric distribution, Similarity.
\end{abstract}

Composição e estrutura de um trecho de floresta tropical na Amazônia Oriental

RESUMO: $O$ objetivo deste estudo foi determinar a diversidade, composição e estrutura florestal de um trecho de floresta ombrófila densa do estado do Amapá. A área está localizada a leste do Estado do Amapá, Amazônia Oriental. Nas seguintes coordenadas: $2^{\circ} 0$ '0,00” $N$. $14^{\circ}$ 0'0.00"O. O processo de amostragem utilizado foi o sistemático em que foram alocadas nove parcelas de 1 ha (100 $\mathrm{m} x 100 \mathrm{~m}$ ), distanciadas em $0.5 \mathrm{~km}$ entre si, dentro de um transecto de $13 \mathrm{~km}$ de comprimento por $0.03 \mathrm{~km}$ de largura. A estrutura horizontal da floresta foi avaliada por meio de parâmetros fitossociológicos. 1790 árvores foram amostradas neste estudo. Elas estão distribuídas em 131 espécies, 69 gêneros e 48 familias. As espécies que apresentaram mais individuos foram Pouteria guianensis Aubl. (136), Eschweilera coriacea (DC.) S.A.Mori (78), Inga paraensis Ducke (45), Licania paraensis Prance (38). A área é altamente diversa e dissimilar com grande variabilidade e complexidade na formação vegetal.

Palavras-chave: Diversidade, Distribuição diamétrica, Similaridade.

\section{INTRODUCTION}

The Amazon forest is composed of vegetal mosaics formed by several species. including trees, palms and vines. It covers more than $70 \%$ of the mainland areas of the Amazon, so it is called the Terra Firme Ombrophilous Forest. Among its characteristics are: the high richness and diversity of species. The high structural variability and dissimilarity between stands (LIMA, 2015; CORDEIRO et al., 2020).

The Amazon is the largest natural reservoir in diversity of terrestrial flora. According to OLIVEIRA \& AMARAL (2004) the floristic composition is extremely rich and strongly influenced by environmental factors such as soil, relief and climate. However, few studies have been carried out seeking to describe and record the characteristics of the forests of Amapá (SOUZA \& EISENLOHR, 2020).

Sustainable development in the Amazon and specifically in Amapá aiming rational use of forest resources is dramatically affected by the lack of knowledge about the floristic composition, forest structure, volume and biomass, making difficult to use sustainable forest management techniques. The expansion of local environmental information is very important, since Amazonian forests help with essential environmental services, such as carbon stocks and the maintenance of the genetic heritage of at least one third of the world's forest biodiversity (KULEVICZ et al., 2020). The lack of knowledge 
favours the loss of vegetation cover and the loss of species diversity (ANDRADE et al., 2020).

Therefore, it is necessary to answer the following question: what are the most important families and species in the population, how are they organized and what is their contribution in volume and biomass to the forest?

Therefore, the objective of this study was to determine the diversity, composition and structure of a stretch of dense ombrophilous forest in the state of Amapá, Eastern Amazon, to contribute with essential information for the conservation and sustainable use of the forest.

\section{MATERIALS AND METHODS}

\section{Characterization of the study area}

The study area is located in the northern portion of the Eastern Amazon, east of the state of Amapá more specifically in the municipality of Pedra Branca do Amapari, has the following coordinates: $2^{\circ}$ 0 ' 0.00 ' N. $14^{\circ} 0$ '0.00 ' 'O (Figure 1).

The climate of the region, according to Köppen, is Amw' (Moçonic tropical climate with summer-autumn rains). The average annual rainfall is approximately $3.225 \pm 138 \mathrm{~mm}$. The temperature has a low thermal amplitude that varies from 24.8 $\pm 0.15{ }^{\circ} \mathrm{C}$ in the coldest month, to $26.9 \pm 0.10$ ${ }^{\circ} \mathrm{C}$ in the hottest month (GOMES SOBRINHO \& SOTTA, 2011).

The vegetation is made up of mainly forests, Rainforest Dense motana (APARÍCIO, 2013). The predominant soil is the dystrophic redyellow latosol. This soil is deep and has low fertility. it occurs in dense forests of firm ground (IEPA, 2008).

\section{Sampling of vegetation}

The sampling was carried out considering the slope and the altitude of the land to represent the vegetation that occurs along the morphometry of the area under study. The sampling system was systematic sampling, nine plots of 1 hectare each $(1 \mathrm{ha}=100 \mathrm{~m}$ $\mathrm{x} 100 \mathrm{~m}$ ) were plotted. $0.5 \mathrm{~km}$ apart in a $13 \mathrm{~km}$ long transect by $0.03 \mathrm{~km}$ long width. The inclusion level adopted was $\mathrm{DBH} \geq 20 \mathrm{~cm}$ (DBH - Diameter at Chest height). The measured variables were: $\mathrm{DBH}$, total height (HT), commercial height (HC).

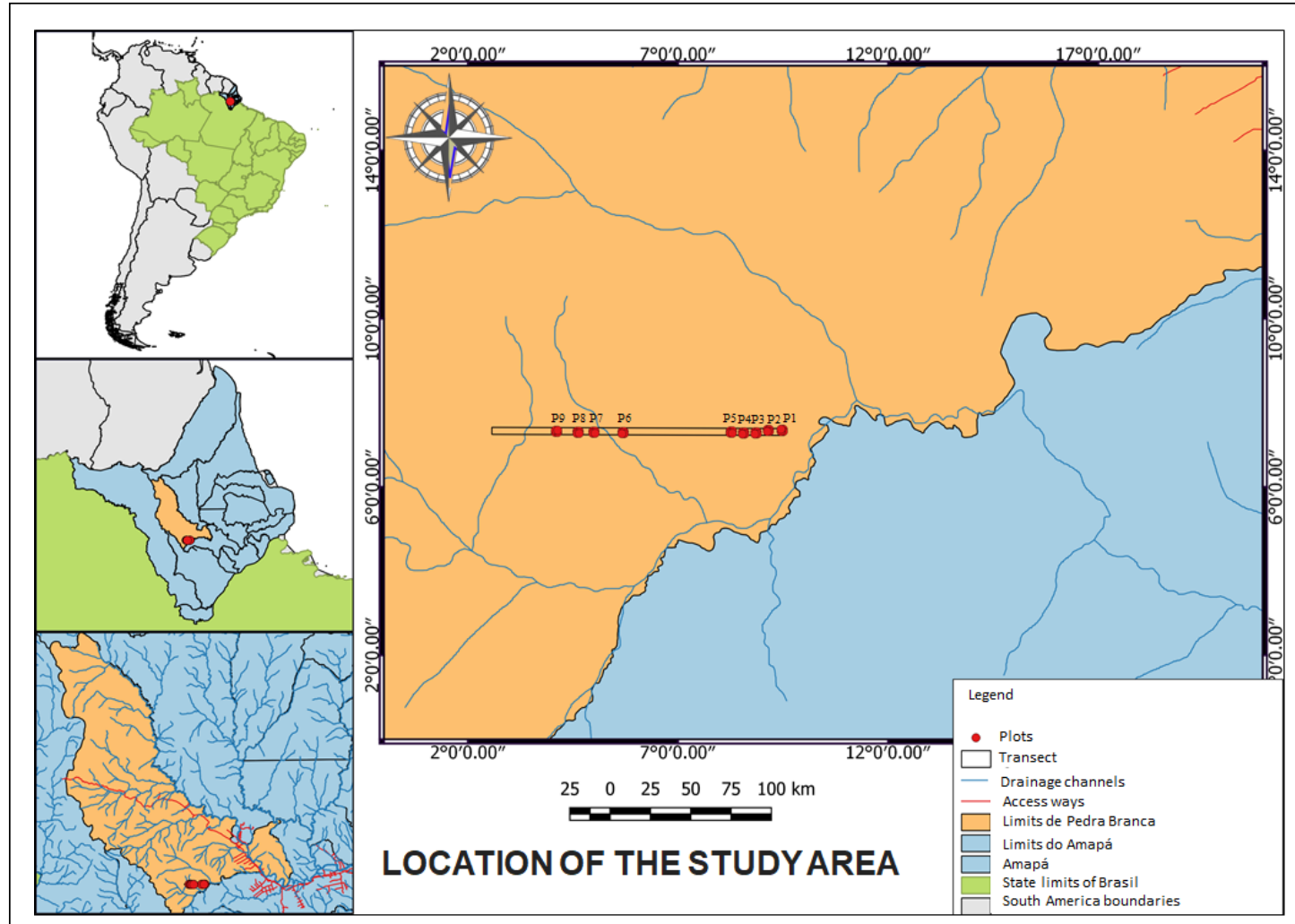

Figure 1 - Location of the study area. state of Amapá. Northern Eastern Amazon. 
Floristic composition, structure, volume and forest biomass

To verify the similarity in the floristic composition, the Jaccad Floristic Similarity Index was applied, Subsequently, to analyze the floristic diversity between the plots, the Shannon Diversity Index $(\mathrm{H}$ ') was applied to verify the distribution of individuals, the Pielou Equability Index (J) was used.

The horizontal structure was evaluated using the phytosociological parameters described by SOARES et al., (2011): Density. Dominance. Frequency and Value of Importance. The diametric distribution was performed by grouping individuals into size classes using the Sturges rule and distribution graphs.

The vertical structure was analyzed through the distribution of individuals according to their HT. The volume was obtained using the equation: $\mathrm{Ln}(\mathrm{Vol})=-8.889+1.881 . \mathrm{Ln}(\mathrm{DAP})+$ $0.875 . \mathrm{Ln}(\mathrm{Ht})+\varepsilon$, where $\mathrm{Ln}(\mathrm{Vol})=$ natural $\log$ of the volume. $\mathrm{Ln} \mathrm{DAP}=$ natural $\log \mathrm{DAP} . \mathrm{Ln} \mathrm{Ht}=$ natural height log. For biomass, the equation was used: Ln $($ BFAS $)=-2.01747+1.99172$. LnDAP +0.071282 $\mathrm{LnHt}+\varepsilon$, in $\mathrm{Ln}(\mathrm{BFAS})=$ natural $\log$ of fresh biomass above ground, natural log of Ln DAP; Ln Ht natural $\log =$ total height of the individual, both equations were provided by LIMA (2015). All data for analysis of forest structures were tabulated in Microsoft Excel spreadsheets, and analyzed with the aid of the $\mathrm{R}$ statistical package and the Rstudio platform.

\section{RESULTS AND DISCUSSION}

Floristic composition, structure, volume and forest biomass

The sampling effort of this study was satisfactory, since the observed sampling error was
$6.926 \%$, less than the $10 \%$ applied in the Amazon rainforest. However, the species accumulation curve did not stabilize, this result indicated that the diversity and richness of the studied site are quite high and suggested the need for a larger number of sample units.

CONDÉ \& TONINI (2013), when studying tropical forests, concluded that the area species curve does not stabilize even with large sampled areas, due to the high richness. SCHILLING et al. (2012) says that the curve is inappropriate to measure sample sufficiency in tropical forests, as it does not stabilize easily, even if sampling is sufficient. Therefore, the sampling effort was considered sufficient for this research.

1790 trees were sampled in this study, they are distributed in 131 species, 69 genera and 48 families. This sampling result is similar to that other studies carried out in tropical forests in the Amazon (OLIVEIRA. 2016). With the same level of inclusion as the current research. SANTOS (2017) studied an area of five hectares of forest in the municipality of Porto Grande / AP, sampled 1.041 trees.

The species that presented more individuals were Pouteria guianensis Aubl. (136), Eschweilera coriacea (DC.) S.A.Mori (78), Inga paraensis Ducke (45), Licania paraensis Prance (38) and Virola michelii Heckel (33), which represent $40 \%$ of the total sample (Figure 2a). The families: Fabaceae (20 species), Lauraceae (7 species), Apocynaceae, Lecythidaceae and Sapotaceae (6 species each); had $49.44 \%$ of the wealth, $53.1 \%$ of families contributed with one species. The most abundant families: Fabaceae (205 individuals), Sapotaceae (150 individuals),
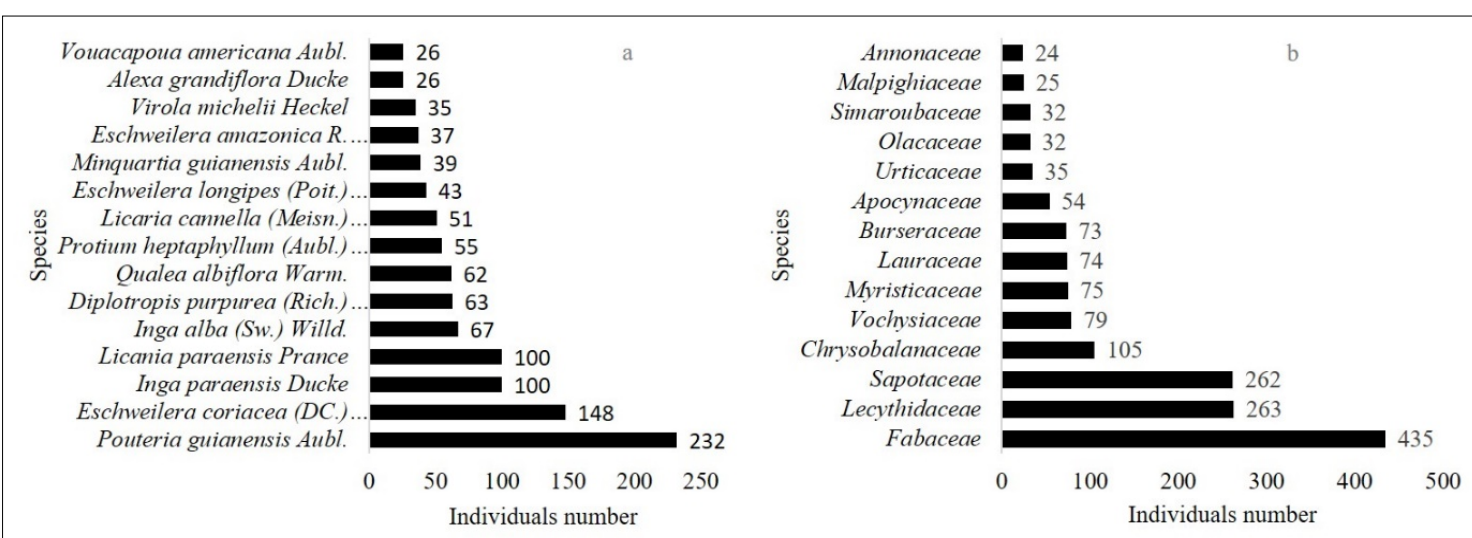

Figure 2- a) Number of individuals per species for the nine plots in the study area. b) Number of individuals per family for the nine plots in the study area. Baixa resolução enviar .tiff com pelo menos 300 dpi. 
Lecythidaceae (120 individuals), Lauraceae (43 individuals) and Chrysobalanaceae (42 individuals), of $67.88 \%$ of the sampled individuals (FIGURE 2b).

The Shannon diversity index $\left(\mathrm{H}^{\prime}\right)$ was equal to 3.57 nats/ind. SILVA et al, (2008) studying an area of firm ground in Manaus/AM, with inclusion level DAP $\geq 20 \mathrm{~cm}$. obtained 2.71 nats/ind. Results above 3.11 nats/ind., indicated a well-preserved plant formation (FERREIRA JUNIOR et al., 2008). Therefore, it can be said that the forest under study has high local floristic diversity.

The Pielou Equability Index (J) was 0.79, this value shows that the forest has a good uniformity in the distribution of individuals by species. CONDÉ $\&$ TONINI (2013), obtained a value of 0.64 for equability by studying a dense ombrophilous forest in the municipality of Caracaraí/RR, this value is considered low for the Amazon. According to some studies (ANDRADE et al., 2015; BATISTA et al., 2015), the levels of uniformity considered high vary between 0.75 and 0.92 .

For similarity, the lowest value obtained occurred when comparing plots P2 and P8 (0.16), corresponding to the high dissimilarity between plots. The average value calculated for similarity was 0.42 , indicating that there is low similarity between the plots. The Jaccard similarity index says that there is similarity between plots with values equal to or above 0.5 , results with values upcoming to or equal to one, refer to the high similarity between plots (FERREIRA JUNIOR et al., 2008).

The species with the highest Importance Value (VI) were: Pouteria guianensis Aubl. (37.7), Eschweilera coriacea (DC.) S.A.Mori (24.9), Inga paraensis Ducke (15.5), Licania paraensis Prance (12.6), representing 52.13\% of the VI (Table 1). CARIM et al. (2013) identified the Fabaceae family as having the highest specific richness, density and relative dominance, followed by Sapotaceae by the size of its species. Similar results to those of PEREIRA et al. (2011), who indicated Fabaceae at the top of importance for dryland forests, followed by Lauraceae and Sapotaceae. The families Lecythidaceae. Lauraceae and Vochysiaceae, also appear in studies carried out in the Amazon (CARIM et al., 2013; CONDÉ \& TONINI, 2013; ANDRADE et al., 2017).

The diametric distribution of the forest was in the form of an "inverted J". with a greater number of young individuals in the smaller diameter classes. and a smaller number of large individuals in the larger diameter classes (Figure 3). This behaviour is reported in balanced forests. that is. forests that are in balance; therefore. the studied forest is framed as a well-preserved forest. Similar results were reported by SANTOS (2017) who used the inclusion level $\mathrm{DBH} \geq 20 \mathrm{~cm}$. The area is highly diverse and dissimilar with great variability and complexity in vegetable formation.

The lowest height sampled was equal to $9 \mathrm{~m}$. and the highest height was $39 \mathrm{~m}$. the average overall height was $18.5 \mathrm{~m}$. Most individuals are between $10 \mathrm{~m}$ and $20 \mathrm{~m}$ height. From $20 \mathrm{~m}$. as the height increases. there is a decrease in the number of individuals in the classes.

The height range of the tree strata depends on the development of the forest (LUANA. 2017). According to SOUZA et al. (2006). the vertical structure becomes an important sustainability indicator when it comes to phytosociological inventory. The species that are represented in the three tree strata represent the vertical structure well. showing that these species dominate the forest. In the present research. 23 species participated in the three tree strata. which represents $25.84 \%$ of the studied population.

Table 1 - Phytosociological parameters of the inventoried forest stretch where IVI = Importance Value Index; FA = Absolute Frequency; $\mathrm{DA}=$ Absolute Density; DoA $=$ Absolute Dominance; FR $=$ Relative Frequency; DR $=$ Relative Density; DoR $=$ Relative Dominance.

\begin{tabular}{lccccccc}
\hline SPECIES & FA & DA & DoA & FR & DR & DR & IVI \\
\hline Pouteria guianensis Aubl. & 8.00 & 232.00 & 22.03 & 2.06 & 12.96 & 8.73 & 23.76 \\
Eschweilera coriacea (DC.) S.A. Mori & 8.00 & 148.00 & 18.77 & 2.06 & 8.27 & 7.44 & 17.77 \\
Licania paraensis Prance & 9.00 & 100.00 & 11.93 & 2.32 & 5.59 & 4.73 & 12.64 \\
Inga paraensis Ducke & 8.00 & 100.00 & 10.43 & 2.06 & 5.59 & 4.13 & 11.78 \\
Qualea albiflora Warm. & 8.00 & 62.00 & 13.33 & 2.06 & 3.46 & 5.28 & 10.81 \\
\hline
\end{tabular}




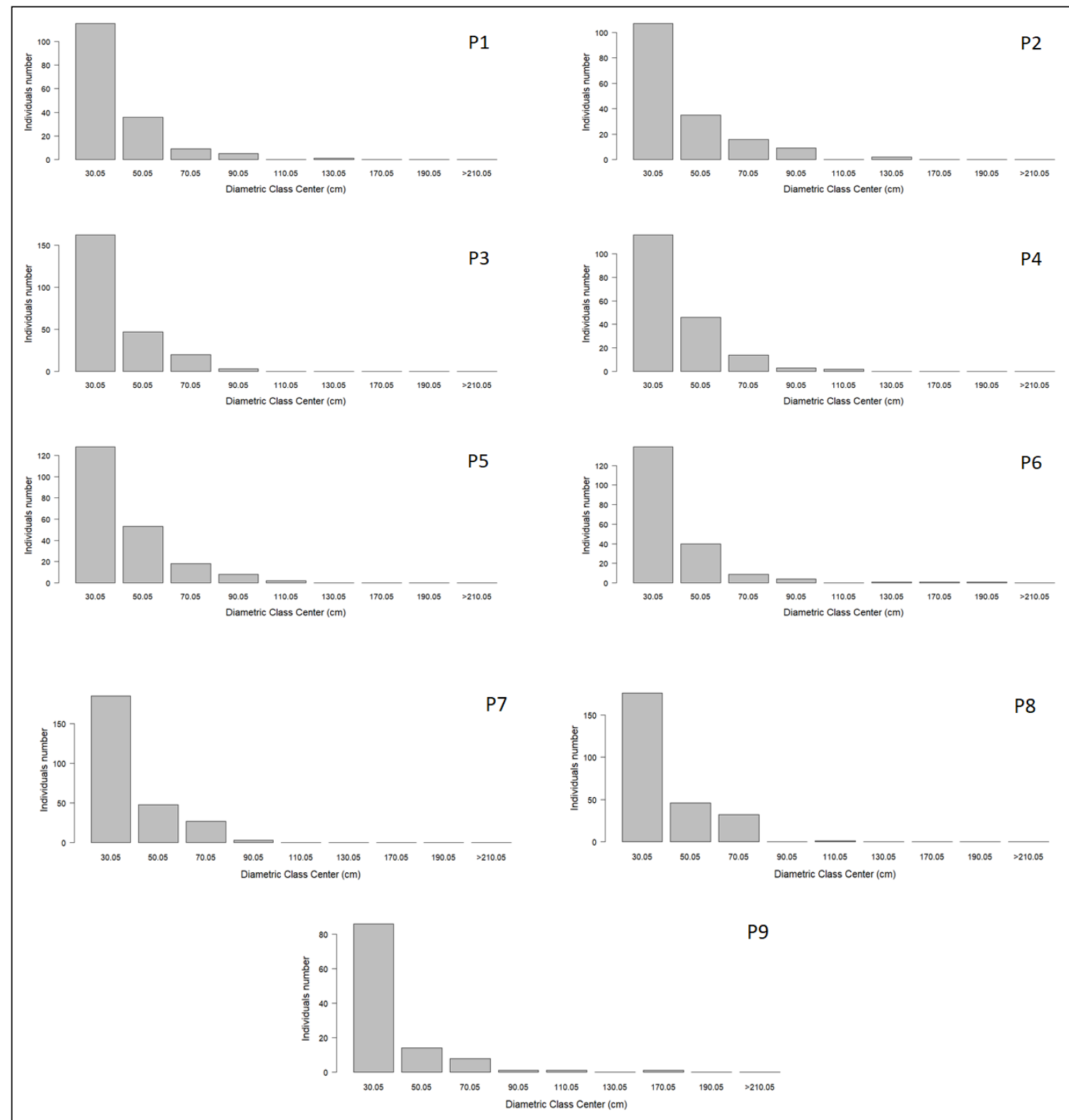

Figure 3 - Diametric distribution for all individuals inventoried in the sampling. Baixa resolução enviar tiff com pelo menos 300 dpi.

SANTOS (2017) studying a forest in Porto Grande/AP. using the same level of inclusion as the current research $(\mathrm{DBH} \geq 20 \mathrm{~cm})$. concentrated most of its individuals in the range of 11 to 27 meters in height. and the average was 18.7 meters. with trees up to 37 meters high. These values approach to the results reported in the present research. corroborating the fact that the forest under study is in an excellent state of conservation.

Volume and biomass showed low estimates in the lower altitude plots and high estimates in the higher altitude plots. The highest estimates for volume occurred in the P5 $\left(625 \mathrm{~m}^{3}\right)$ and P6 $\left(576 \mathrm{~m}^{3}\right)$ plots. For biomass. the highest estimates were in P5 $(73 \mathrm{t})$ and P6 $\left(66 \mathrm{~m}^{3}\right)$ plots (Figure 4).

\section{CONCLUSION}

The studied forest stretch has high diversity. which is mainly composed by the families Fabaceae. Sapotaceae. Lecythidaceae and the

Ciência Rural, v.51, n.4, 2021. 

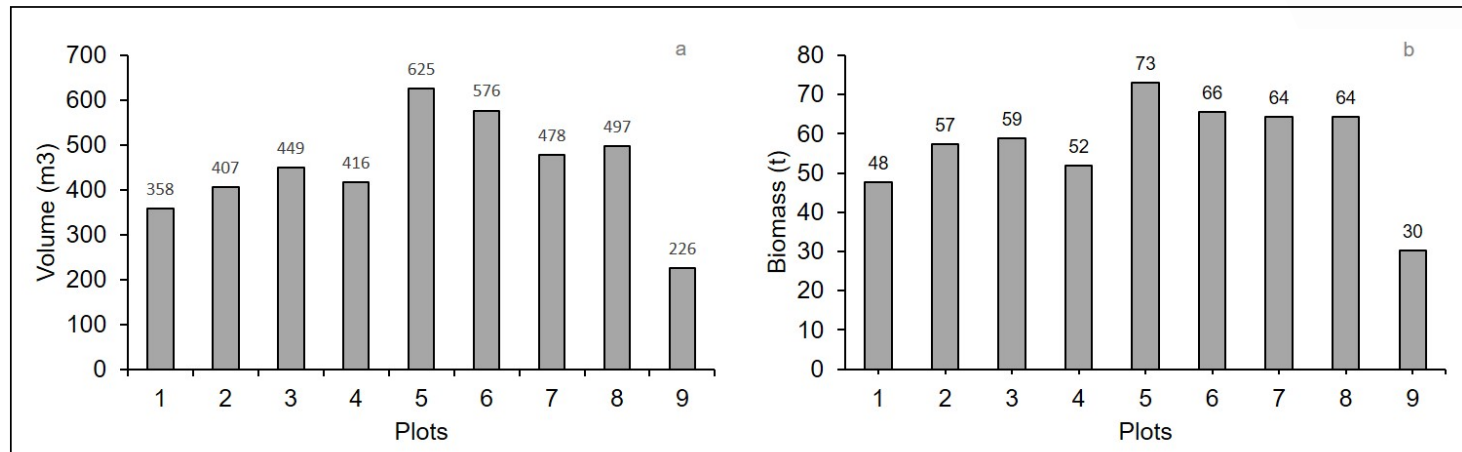

Figure 4 - a) Estimates of wood volume in plots of 1 (one hactare). in a tropical forest in the Eastern Amazon. b) Estimates of forest biomass in plots of 1 (one hactare). in a tropical forest in the Eastern Amazon.

species Pouteria guianensis Aubl.. Eschweilera coriacea (DC.) S.A.Mori. Inga paraensis Ducke. Licania paraensis Prance. Dinizia excelsa Ducke. The structure exhibits a pattern with few trees with large diameters and median height of the canopy ( 35 to $40 \mathrm{~m}$ ). The vertical structure follows the relief; the volume and the biomass are smaller in low altitude plots and larger in higher altitude plots.

\section{ACKNOWLEDGEMENTS}

The work was financed by Research Support Foundation of Amapá - FAPEAP, through the public call GUYAMZON III for study "Integration of multiscale spatial data for mapping forest types and biomass in Amapá and French Guiana - BIOMAP".

\section{DECLARATION OF CONFLICTS OF INTERESTS}

The authors declare no conflict of interest. The founding sponsors had no role in the design of the study; in the collection. analyses. or interpretation of data; in the writing of the manuscript. and in the decision to publish the results.

\section{AUTHORS' CONTRIBUTIONS}

All authors contributed equally for the conception and writing of the manuscript. All authors critically revised the manuscript and approved of the final version.

\section{REFERENCES}

ANDRADE. D. F. C. et al. Composição e estrutura de uma floresta primária atingida por incêndio florestal na Amazônia Oriental. Ciência Florestal. Santa Maria. v.30. n.1. p.145-160. jan./mar. 2020.

ANDRADE. D. F.; G. et al. Inventário florestal de grandes áreas na Floresta Nacional do Tapajós. Pará. Amazônia. Brasil. Biota Amazônia. Macapá-AP. v.5. n.1. p.109-115. 2015.
ANDRADE. R. T. G.et al. Fitossociologia de uma floresta de terra firma na Amazônia Sul-Ocidental. Rondônia. Brasil. Biota Amazônia. Macapá-AP. v.7. n.2. p.36-43. 2017.

APARÍCIO P. S. Subsídios para o manejo sustentável na Floresta Estadual do Amapá: estrutura e dinâmica. 2013. 138 p. Tese (Doutorado em Biodiversidade Tropical) - Programa de Pós-Graduação em Biodiversidade Tropical. Universidade Federal do Amapá. Macapá. 2013.

BATISTA. A. P. Caracterização estrutural em uma floresta de terra firme no estado do Amapá. Brasil. PFB. Colombo. v.35. n.81. p.2133. jan./mar. 2015.

CORDEIRO. A. G. M. et al. Diversidade genética entre cupuízeiros nativos do Portal da Amazônia. Mato Grosso. Brasil. Scientific Electronic Archives. Vol. 13 (3) 2020.

CARIM. M. J. V. et al. Composição e estrutura de floresta ombrófila densa do extremo norte do Estado do Amapá. Brasil. Biota Amazônia. Macapá-AP. v.3. n.2. p.1-10. 2013.

CONDÉ. T. M.; TONINI. H. Fitossociologia de uma floresta ombrófila densa na Amazônia setentrional. Roraima. Brasil. Acta Amazônica. v. 43. n. 3. p. 247-260. 2013.

FERREIRA JUNIOR. E. V. et al. Composição. diversidade e similaridade florística de uma floresta tropical semidecídua submontana em Marcelândia-MT. Acta Amazonica. v.38. n.4. p.673-680. 2008.

GOMES SOBRINHO. T. R.; SOTTA. E. D. Caracterização climatológica do Módulo 4 da floresta estadual do Amapá FLOTA/AP: dados preliminares. Macapá-AP. 2011.

INSTITUTO DE PESQUISAS CIENTÍFICAS E TECNOLOGICAS DO ESTADO DO AMAPÁ (IEPA). Macrodiagnóstico do estado do Amapá. primeira aproximação do ZEE. 3. ed. Revisada e Ampliada. Macapá-AP. 139 p. 2008

KULEVICZ R. A. et al. Sanalysis of forests' genetic vulnerability and arguments to reduce deforestation. Ambiente \& Sociedade. São Paulo. Vol. 23. 2020.

LIMA. R. C. Equações para estimativas de biomassa de uma Floresta tropical úmida do Amapá. 2015. 48 p. Dissertação (Mestrado em Ciências Florestais) - Programa de Pós-Graduação em Ciências Florestais Universidade Federal Rural de Pernambuco. Recife. 2015. 
LUANA. F. B. P. Análise da fitossociologia de uma área de terra firme no Rio Maués Mirim. município de Maués-AM. Dissertação. Itacoatiara-AM. 2017.

OLIVEIRA. A.N.; AMARAL. I.L. 2004. Florística e fitossociologia de uma floresta de vertente na Amazônia Central. Amazonas. Brasil. Acta Amazonica. 34:21-34

OLIVEIRA. W. L. Estrutura. regras de montagem e dinâmica de florestas de terra firme. várzea e campinaranas: respostas ao gradiente ambiental e reservatório de uma hidrelétrica na Amazônia. bacia do alto Rio Madeira-RO. Tese de doutorado. Brasília-DF. 2016.

PEREIRA. L. A. et al. S. V da. Florística e estrutura de uma mata de terra firme na Reserva de Desenvolvimento Sustentável Rio Iratapuru. Amapá Amazônia Oriental. Brasil. FLORESTA. Curitiba. PR. v.41. n.1. p.113122. jan./mar. 2011
SANTOS. K. P. C. Detecção da estrutura florestal aplicando o método foto em ecossistema de terra firme na Amazônia Oriental: primeiros resultados. Dissertação. Macapá-AP. 2017.

SCHILLING. A. C. et al. Ausência de estabilização da curva de acumulação de espécies em florestas tropicais. Ciência Florestal. Santa Maria-RS. v.22.n.1. p.101-111. jan./mar.. 2012.

SILVA. K. E. et al. Composição florística e fitossociologia de espécies arbóreas do Parque Fenológico da Embrapa Amazônia Ocidental. Acta Amazônia. v.38. n.2. p.213-222. 2008.SOARES. C. P. B.; NETO. F. P.; SOUZA. A. L. Dendrometria e Inventário Florestal. Editora UFV. Viçosa-MG. 272p. 2011.

SOUZA. L. A; EISENLOHR. P.V. Drivers of floristic variation in biogeographic transitions: insights from the ecotone between the largest biogeographic domains of South America.Acta Botanica Brasilica - 34(1): 155-166. 2020. 